Article

\title{
Impact of Carbon Emission Trading System Participation and Level of Internal Control on Quality of Carbon Emission Disclosures: Insights from Chinese State-Owned Electricity Companies
}

\author{
Duojiao Tan ${ }^{1}$, Bilal $^{1, *}$, Simon Gao ${ }^{2}$ and Bushra Komal ${ }^{3, *}$ \\ 1 School of Accounting, Hubei University of Economics, Wuhan 430205, China; tanduojiao@hbue.edu.cn \\ 2 The Business School, Edinburgh Napier University, Edinburgh EH11 1DJ, UK; s.gao@napier.ac.uk \\ 3 The Business School, University of International Business and Economics, Beijing 100029, China \\ * Correspondence: bilal@hbue.edu.cn (B.); bushrakomal@hotmail.com (B.K.)
}

Received: 7 January 2020; Accepted: 25 February 2020; Published: 27 February 2020

check for updates

\begin{abstract}
In recent years, the quality of carbon emission disclosures has become a central area of concern for different stakeholders of companies. Specifically, stakeholders of state-owned enterprises (SOEs) want these companies to legitimize their actions regarding carbon emissions reductions reporting. The current study aims to explore the impact of carbon emission trading system participation and the level of internal control on the quality of carbon emission disclosures. Using a sample of Chinese state-owned electricity companies from 2012 to 2018 and employing the difference-in-differences (DID) method, we find a positive impact of the carbon emission trading system participation on the quality of carbon emission disclosures, which suggests that the state-owned electricity companies' participation in the carbon emission trading system leads to the higher quality of carbon emission disclosures. Likewise, we find a positive relationship between the level of internal control and the quality of carbon emission disclosures, which suggests that the state-owned electricity companies with stronger internal control provide the higher quality of carbon emission disclosures. In addition, we find that the findings are only significant in the case of central SOEs as compared to local SOEs. Our findings contribute to the practical, policy, and research implications as the quality of carbon disclosures is the primary concern from a variety of stakeholders.
\end{abstract}

Keywords: carbon emission disclosures; low carbon; carbon emission trading system; internal control; electricity companies; state-owned enterprises

\section{Introduction}

Carbon emission disclosures are required by different stakeholders such as the government, investors, regulators, and the general public of the companies to legitimize their environmental performance due to global warming. In particular, state-owned enterprises (SOEs) in China are facing more pressure from the government and the public to disclose more information regarding carbon emission reductions [1,2]. However, the quality of the carbon emission disclosures is the main concern of the stakeholders because it is extremely low in China from the benchmarks as compared to the developed countries [3]. Carbon emission disclosures among SOEs in China are provided for political rent-seeking purposes [4], as SOEs aim to achieve more complex goals comprising economic profit and political goals such as maintaining social stability and promoting policy implementation. Thus, the quality of carbon disclosures in SOEs is uncertain.

Chinese state-owned electricity companies are selected for the following reasons. First, China's electricity sector is one of the largest carbon emitters among Chinese economic sectors [5-8]. Given 
more stringent binding targets for carbon emissions, the Chinese government has adopted several policies and measures that remarkably improve the energy structure and energy efficiency in this sector $[8,9]$. Second, China's electricity sector is going to be the first fully implementing sector in China's national emission trading scheme. China's emissions trading system (CN-ETS) was implemented in 7 pilot regions in 2013; CN-ETS pilot schemes are unique and provide a solid base for building China's national emission trading scheme [10]. In setting up the CN-ETS system, China followed the guidelines of European ETS for effective functioning [11]. The seven CN-ETS pilots were constructed on provincial and municipal administrative rules as their central legal enforcement and accompanied by relevant local standards. Several recent studies have examined the effectiveness of CN-ETS pilots in China [10,12-14]. However, there is a lack of consideration of the impact of the participation of electricity companies in CN-ETS on the quality of their carbon disclosures. Thus, our study aims to explore the influence of CN-ETS participation on the quality of carbon disclosures in Chinese state-owned electricity companies. In addition, our study wants to explore the impact of the level of internal control on the quality of carbon information disclosures in Chinese state-owned electricity companies.

Internal control has gained significant importance in sustainability disclosures in the Chinese context. As Chinese regulators (e.g., The Ministry of Finance, and the other four regulators) issued the specific internal control policies in 2010. Specifically, regulators require Chinese companies to fulfil social obligations by complying with national rules and regulations under Article 1 of the "Application Guideline No.4 of Enterprise Internal Control-Social Responsibility". A few studies have examined the impact of these policies on corporate social responsibility and carbon disclosures [15-20]. However, there is no evidence regarding the impact of the level of internal control on the quality of carbon information disclosures in Chinese state-owned electricity companies.

In this study, we have investigated the impact of CN-ETS participation and the level of internal control on the quality of carbon disclosures in Chinese state-owned electricity companies. We have measured the quality of carbon emission disclosures through an index of 0-54 scores based on the presence or absence of eighteen carbon disclosures items multiplied with their specific quality level (0-3) by following Choi et al. (2013) [21] and Lee (2017) [22]. We have manually collected the data of electricity companies' participation or a registration in the CN-ETS in their concerned markets from 2012 to 2018. Finally, the level of internal control is measured through publically available Dibo Index. After applying the DID method, we find a positive impact of the carbon emission trading system on the quality of carbon emission disclosures, which suggests that the state-owned electricity companies' participation in the carbon emission trading system leads to a higher quality of carbon emission disclosures. Likewise, we find a positive relationship between the level of internal control and quality of carbon emission disclosures, which suggests that the state-owned electricity companies with stronger internal control provide the higher quality of carbon emission disclosures. In addition, we find that the findings are only significant in the case of central SOEs. Our findings contribute to the practical, policy, and research implications as the quality of carbon disclosures is the primary concern from a variety of stakeholders. Our study also contributes to the emerging carbon emission disclosures literature. Our findings have implications for managers and regulators of Chinese state-owned electricity companies to legitimize their actions by providing more quality carbon emission disclosures. Managers should enhance the level of carbon disclosures to provide more quality information to different stakeholders regarding climate change risks and opportunities. We also urge the regulators to facilitate and monitor the companies for higher carbon disclosures for different stakeholders.

The rest of the paper is structured as follows. The second section contains the prior literature and hypothesis development. The third section describes data, sample and research methodology. While the fourth section presents the results and discussion, and the final section concludes the study. 


\section{Literature Review and Research Hypothesis}

\subsection{Carbon Emission Trading System and Quality of Carbon Emission Disclosures}

According to the 12th and 13th five-year plans of the Chinese government to control greenhouse gas (GHG) emissions, the establishment of a national carbon emissions trading market is required, which should be promoted and implemented after December 30, 2014 [23]. Under the carbon trading system, if the GHG emissions of a company exceed the free allocation limit prescribed by the government for a certain period, then the excess amount of carbon quota must be purchased from the market [24]. In the carbon market, for buyers, the purchase of carbon emissions is equivalent to the cost of "carbon assets" which will affect corporate profits; for sellers, the sales proceeds are obtained [25].

China introduced seven pilot schemes in 2013. Since the implementation of CN-ETS, its effectiveness becomes a hot issue for regulators and academicians in China [26-32]. Prior research concludes that the implementation of an ETS can effectively improve the carbon transparency of companies [33,34]. However, carbon disclosures vary significantly across different sectors [34]. Momin et al. (2017) [7] analyzed the extent of carbon disclosures of Chinese electricity companies and claimed that carbon disclosures practices were largely symbolic. However, there is no evidence regarding the impact of CN-ETS on the quality of carbon emission disclosures of Chinese state-owned electricity companies. Prior research indicates that the stakeholders of the companies that participate in ETS demand a significant amount of information regarding carbon reductions [34-36]. According to stakeholder and legitimacy theories [37,38], the managers pursue socially responsible objectives to fulfil the expectations of different stakeholders to maximize their wealth/interests and provide more transparent information in the sustainability reports. Thus, Chinese companies that participate in CN-ETS requires to be more transparent in terms of their carbon reductions and environmental commitments. Based on the above, we expect that Chinese state-owned electricity companies' participation in CN-ETS leads to a higher quality of their carbon emission disclosures. If the quality of carbon emission disclosures reaches the requirement before accessing/participating in CN-ETS, it expects to to have less or no change in the quality of disclosures. However, prior evidence indicates that this is not the case concerning CN-ETS as the quality of carbon emission disclosures in Chinese companies is low [3,7]. Hence, we claim that CN-ETS participation significantly influences the quality of the carbon emission disclosures and hypothesizethat:

Hypothesis 1 (H1). There is a positive relationship between the companies participated in CN-ETS and the quality of their carbon emission disclosures.

\subsection{Internal Control and Quality of Carbon Emission Disclosures}

According to agency theory, effective internal control indicates a strong internal environment with reliable environmental reporting [39-41]. The internal control regulations state that the objective of internal control is to ensure the reliability of financial reporting, improve the effectiveness of business operations, and comply with laws and regulations [42]. Internal control is a process of realizing an internal system plan based on continuous supervision [43]. Prior literature on sustainability disclosures claims that effective internal control enhances the disclosure quality which helps the companies to meet the disclosure demand of different stakeholders $[15,16,44]$. In the existing literature, very few studies have linked internal control effectiveness with carbon disclosures. Li and Zhang (2017) [44] find that the environmental spillover effect of internal control is an essential factor in improving the quality of environmental information disclosures. Qiao (2015) [20] points out that there is a significant positive correlation between the effectiveness of internal control and the level of carbon information disclosure in high polluting firms. Chen (2016) [19] considers that the level of carbon information disclosure can be improved through perfecting the internal control of companies. Ren and $\mathrm{Li}$ (2018) [18] find that the level of internal control is the influencing factor of whether a company responds to the CDP questionnaire and the quality of carbon information disclosure is positively correlated with the level 
of internal control. We expect, based on prior findings, Chinese state-owned electricity companies with strong or weak internal control significantly influence the quality of carbon emission disclosures. Therefore, this paper puts forward Hypothesis 2:

Hypothesis 2 (H2). The level of internal control is significantly related to the quality of carbon information disclosures.

\section{Data, Sample and Research Methodology}

The current study selects the data of the state-owned electricity companies from 2012 to 2018. The information related to carbon emission disclosures of companies in the sample comes from the stand-alone corporate social responsibility (CSR) reports and/or annual reports. The information regarding companies' participation in CN-ETS is collected from the websites of the concerned Carbon Emission Exchanges. The data regarding the level of internal control is collected from the Dibo Index. The data for control variables is collected from the China Stock Market \& Accounting Research (CSMAR) database. After merging all variables from different sources, we have a final sample of 356 firm-year observations of state-owned electricity companies from 2012-2018, as shown in Table 1. Initially, we had an unbalanced panel of 423 firm-year observations from 66 companies that took part in CN-ETS. For the purpose of this study, we have excluded the data from privately-owned electricity companies and companies with missing data.

Table 1. Sample selection criteria.

\begin{tabular}{cc}
\hline Criteria & Observations \\
\hline The initial sample of electricity companies from 2012-2018 & 423 \\
Less: Privately owned/ non-state owned companies & $(42)$ \\
Less: Missing data for independent and control variables & $(25)$ \\
Final firm-year observations from 2012-2018 & 356 \\
\hline
\end{tabular}

The regression model of the study is as follows:

$$
\mathrm{QCDI}_{\mathrm{it}}=\beta_{0}+\beta_{1} \mathrm{~T}_{\mathrm{it}}+\beta_{2} \mathrm{ETS}(\text { treat })_{\mathrm{it}}+\beta_{3} \mathrm{~T}^{*} \mathrm{ETS}_{\mathrm{it}}+\beta_{4} \mathrm{LCE}_{\mathrm{it}}+\text { Control }_{\mathrm{it}}+\mu_{\mathrm{it}} .
$$

The primary coefficients in the above regression models are $\beta_{1}$ (ETS) and $\beta_{4}$ (LCE) that predicted to be positive. Our study employs the difference-in-differences (DID) method to explore the impact of CN-ETS participation on the quality of carbon emission disclosures. The DID is the most appropriate method for evaluating the impact of CN-ETS implementation on the quality of carbon emission disclosures as suggested by the prior literature [45-48].

The description of the variables used in our study are as follows:

The dependent variable, QCDI is the quality of carbon emission disclosures measured through the content analysis of 18 items in the following two steps. In the first step, following Choi et al. (2013) [21], we extract the carbon emission disclosures from stand-alone CSR and/or annual reports of electricity companies based on 18 carbon disclosure items from five different dimensions of climate-change-related issues such as 1) climate-change risks and opportunities; 2) GHG emissions accounting; 3) energy consumption accounting; 4) GHG reduction and cost; and 5) carbon emission accountability. In the second step, following Lee (2017) [22], our study uses 0-3 scores to ensure the quality of carbon emission disclosures based on the following criteria:

- General disclosure (1): The company has provided the information of a particular carbon emission disclosure item in general without any precise explanations.

- Non-quantitative disclosure (2): The company has provided specific information about a particular carbon emission disclosure item without any facts and figures. 
- Quantitative disclosure (3): The company has provided the quantitative information of a particular carbon emission disclosure item.

The maximum score granted to a company is 54 in a case when a company discloses quantitative disclosures of all 18 items (e.g., 18*3). Finally, our study measures the quality of carbon emission disclosures (QCDI) through an index of $0-54$ scores, which is the ratio of scores obtained by a company in a year divided by the maximum score (e.g., 54) for carbon disclosures.

Independent variables, according to the literature review and research assumptions, this paper takes $\mathrm{t}$ as time period, participation in CN-ETS as the treatment variable, the interaction of both time period and treatment ( $T$ * ETS) as the DID estimation, and internal control effectiveness as an explanatory variable. First, the participation of companies in CN-ETS is measured as a dummy variable, 1 for participation, and 0 for non-participation. The second variable, internal control effectiveness, is measured through the Dibo Index as used in prior studies [15,16].

In line with prior studies such as Choi et al. (2013) [21], Kashyap (2016) [36], and Tang and Luo (2011) [34], the size of the company, board size, CEO duality, profitability, solvency, auditor selection, and company's growth are included as control variables as these variables significantly influence the quality of carbon emission disclosures. The definitions of variables are shown in Table 2.

Table 2. Variables definitions.

\begin{tabular}{|c|c|c|c|}
\hline $\begin{array}{l}\text { Variable } \\
\text { Type }\end{array}$ & Variable Name & Variable Symbol & Variable Definition \\
\hline $\begin{array}{l}\text { Dependent } \\
\text { variables }\end{array}$ & $\begin{array}{l}\text { Quality of carbon } \\
\text { emission disclosures }\end{array}$ & QCDI & $\begin{array}{l}\text { Using a two-step measure to determine } \\
\text { QCDI: The first stage uses content analysis } \\
\text { to identify } 18 \text { carbon emission disclosures } \\
\text { items as did of Choi et al. (2013) [21]; the } \\
\text { second step follows Lee (2017) [22] to score } \\
\text { with 0-3 the quality of carbon emission } \\
\text { disclosures. }\end{array}$ \\
\hline \multirow{3}{*}{$\begin{array}{l}\text { Explanatory } \\
\text { variables }\end{array}$} & $\begin{array}{l}\text { Carbon emission trading } \\
\text { system (treat) }\end{array}$ & ETS & Participated in ETS,1; otherwise, 0. \\
\hline & Time period & $\mathrm{T}$ & $\begin{array}{l}\text { Before and after the carbon emission } \\
\text { trading system started; after 1; before, } 0 \text {. }\end{array}$ \\
\hline & Internal control & LCE & $\begin{array}{c}\text { Natural log of the Dibo internal control } \\
\text { index. }\end{array}$ \\
\hline \multirow{7}{*}{$\begin{array}{l}\text { Control } \\
\text { variable }\end{array}$} & Company size & SIZE & $\begin{array}{c}\text { Natural log of the total assets at the end of } \\
\text { the year. }\end{array}$ \\
\hline & Board size & BS & $\begin{array}{l}\text { Natural log of the total number of directors } \\
\text { in a year. }\end{array}$ \\
\hline & $\begin{array}{l}\text { Position of chairman and } \\
\text { CEO }\end{array}$ & DUAL & $\begin{array}{c}\text { Taken } 1 \text { if one person acting as both CEO } \\
\text { and chairman; } 0 \text { otherwise. }\end{array}$ \\
\hline & Profitability & ROA & Return on assets. \\
\hline & Solvency & LEV & Asset-liability ratio. \\
\hline & Company growth & GROW & $\begin{array}{c}\text { Natural log of the growth rate of total sales } \\
\text { volume in the current year as compared to } \\
\text { the previous year's sales volume. }\end{array}$ \\
\hline & Auditor & BIG4 & $\begin{array}{c}\text { Taken } 1 \text { if the external auditor of the } \\
\text { company is from a Big } 4 \text { audit firm, } 0 \\
\text { otherwise. }\end{array}$ \\
\hline
\end{tabular}

Finally, additional analysis is performed by splitting the sample into the Chinese central government-owned and local government-owned companies as did in prior studies [49-51]. Sensitivity analysis is conducted by using the five dimensions of climate-change-related issues such as 1) climate-change risks and opportunities; 2) GHG emissions accounting; 3) energy consumption accounting; 4) GHG reduction and cost; and 5) carbon emission accountability of the quality of carbon emission disclosures on overall sample, the Chinese central government-owned and local government-owned companies sub-samples. 


\section{Results and Discussion}

Table 3 presents the actual frequency of the quality of carbon emission disclosures (QCED) out of the total 54 points (e.g., all disclosures items $18^{*} 3$ with quantitative disclosures) Panel A of Table 3 presents the results of Chinese state-owned electricity companies, It shows that Chinese state-owned companies have scored 6 points on average out of a maximum of 54 points of carbon emission disclosures. Although in the period of 2012-2018, the extent of carbon emission disclosures of Chinese state-owned electricity companies was improved as compared to the GHG disclosures from 2000-2009 of eight Chinese electricity companies as shown in Momin et al. (2017) [7], our findings indicate that the quality of carbon emission disclosures is still very low for the Chinese state-owned electricity companies.

Table 3. Frequencies of carbon emission disclosures.

\begin{tabular}{|c|c|c|c|c|c|c|c|c|}
\hline \multicolumn{9}{|c|}{ Panel A: Overall sample of state-owned electricity companies (median value $=06$ ). } \\
\hline QCED & 2012 & 2013 & 2014 & 2015 & 2016 & 2017 & 2018 & Total \\
\hline 0 & 9 & 8 & 8 & 5 & 5 & 4 & 4 & 43 \\
\hline 1 & 3 & 4 & 4 & 6 & 3 & 4 & 3 & 27 \\
\hline 2 & 7 & 8 & 7 & 4 & 6 & 3 & 3 & 38 \\
\hline 3 & 4 & 2 & 1 & 3 & 4 & 5 & 4 & 23 \\
\hline 4 & 8 & 7 & 6 & 3 & 2 & 2 & 2 & 30 \\
\hline 5 & 2 & 1 & 3 & 1 & 2 & 1 & 1 & 11 \\
\hline 6 & 3 & 5 & 5 & 4 & 4 & 5 & 7 & 33 \\
\hline 7 & 3 & 4 & 4 & 5 & 3 & 6 & 5 & 30 \\
\hline 8 & 4 & 4 & 5 & 5 & 5 & 5 & 7 & 35 \\
\hline 9 & 0 & 0 & 1 & 3 & 2 & 1 & 2 & 9 \\
\hline 10 & 3 & 3 & 3 & 3 & 3 & 3 & 3 & 21 \\
\hline 11 & 4 & 4 & 4 & 2 & 2 & 1 & 0 & 17 \\
\hline 12 & 0 & 0 & 0 & 2 & 1 & 1 & 1 & 5 \\
\hline 13 & 0 & 0 & 0 & 2 & 3 & 2 & 2 & 9 \\
\hline 14 & 0 & 0 & 1 & 1 & 1 & 2 & 1 & 6 \\
\hline 15 & 0 & 0 & 0 & 0 & 2 & 1 & 1 & 4 \\
\hline 16 & 0 & 0 & 0 & 0 & 1 & 3 & 1 & 5 \\
\hline 17 & 0 & 0 & 0 & 0 & 0 & 1 & 2 & 3 \\
\hline 18 & 0 & 0 & 0 & 0 & 0 & 1 & 0 & 1 \\
\hline 19 & 0 & 0 & 0 & 1 & 0 & 0 & 2 & 3 \\
\hline 20 & 0 & 0 & 0 & 0 & 0 & 0 & 1 & 1 \\
\hline 22 & 0 & 0 & 0 & 0 & 0 & 1 & 1 & 2 \\
\hline Total & 50 & 50 & 52 & 50 & 49 & 52 & 53 & 356 \\
\hline \multicolumn{9}{|c|}{ Panel B: Central government-owned electricity companies (median value = 07). } \\
\hline QCED & 2012 & 2013 & 2014 & 2015 & 2016 & 2017 & 2018 & Total \\
\hline 0 & 4 & 4 & 4 & 2 & 2 & 2 & 2 & 20 \\
\hline 1 & 1 & 2 & 2 & 4 & 2 & 2 & 1 & 14 \\
\hline 2 & 3 & 3 & 2 & 2 & 3 & 1 & 1 & 15 \\
\hline 3 & 1 & 0 & 0 & 1 & 2 & 3 & 2 & 9 \\
\hline 4 & 2 & 2 & 1 & 0 & 0 & 0 & 2 & 7 \\
\hline 5 & 1 & 1 & 1 & 0 & 0 & 0 & 0 & 3 \\
\hline 6 & 1 & 2 & 2 & 1 & 1 & 0 & 0 & 7 \\
\hline 7 & 1 & 1 & 2 & 2 & 1 & 4 & 3 & 14 \\
\hline 8 & 2 & 2 & 3 & 3 & 3 & 2 & 3 & 18 \\
\hline 9 & 0 & 0 & 1 & 2 & 2 & 1 & 2 & 8 \\
\hline 10 & 2 & 2 & 2 & 2 & 2 & 2 & 2 & 14 \\
\hline 11 & 2 & 2 & 2 & 2 & 1 & 1 & 0 & 10 \\
\hline 13 & 0 & 0 & 0 & 1 & 1 & 1 & 1 & 4 \\
\hline 14 & 0 & 0 & 0 & 0 & 1 & 1 & 0 & 2 \\
\hline 15 & 0 & 0 & 0 & 0 & 1 & 1 & 1 & 3 \\
\hline 16 & 0 & 0 & 0 & 0 & 1 & 3 & 1 & 5 \\
\hline 17 & 0 & 0 & 0 & 0 & 0 & 0 & 1 & 1 \\
\hline 19 & 0 & 0 & 0 & 1 & 0 & 0 & 1 & 2 \\
\hline 20 & 0 & 0 & 0 & 0 & 0 & 0 & 1 & 1 \\
\hline 22 & 0 & 0 & 0 & 0 & 0 & 1 & 1 & 2 \\
\hline Total & 20 & 21 & 22 & 23 & 23 & 25 & 25 & 159 \\
\hline
\end{tabular}


Table 3. Cont.

\begin{tabular}{|c|c|c|c|c|c|c|c|c|}
\hline \multicolumn{9}{|c|}{ Panel C: Local government-owned electricity companies (median value $=05$ ). } \\
\hline QCED & 2012 & 2013 & 2014 & 2015 & 2016 & 2017 & 2018 & Total \\
\hline 0 & 5 & 4 & 4 & 3 & 3 & 2 & 2 & 23 \\
\hline 1 & 2 & 2 & 2 & 2 & 1 & 2 & 2 & 13 \\
\hline 2 & 4 & 5 & 5 & 2 & 3 & 2 & 2 & 23 \\
\hline 3 & 3 & 2 & 1 & 2 & 2 & 2 & 2 & 14 \\
\hline 4 & 6 & 5 & 5 & 3 & 2 & 2 & 0 & 23 \\
\hline 5 & 1 & 0 & 2 & 1 & 2 & 1 & 1 & 8 \\
\hline 6 & 2 & 3 & 3 & 3 & 3 & 5 & 7 & 26 \\
\hline 7 & 2 & 3 & 2 & 3 & 2 & 2 & 2 & 16 \\
\hline 8 & 2 & 2 & 2 & 2 & 2 & 3 & 4 & 17 \\
\hline 9 & 0 & 0 & 0 & 1 & 0 & 0 & 0 & 1 \\
\hline 10 & 1 & 1 & 1 & 1 & 1 & 1 & 1 & 7 \\
\hline 11 & 2 & 2 & 2 & 0 & 1 & 0 & 0 & 7 \\
\hline 12 & 0 & 0 & 0 & 2 & 1 & 1 & 1 & 5 \\
\hline 13 & 0 & 0 & 0 & 1 & 2 & 1 & 1 & 5 \\
\hline 14 & 0 & 0 & 1 & 1 & 0 & 1 & 1 & 4 \\
\hline 15 & 0 & 0 & 0 & 0 & 1 & 0 & 0 & 1 \\
\hline 17 & 0 & 0 & 0 & 0 & 0 & 1 & 1 & 2 \\
\hline 18 & 0 & 0 & 0 & 0 & 0 & 1 & 0 & 1 \\
\hline 19 & 0 & 0 & 0 & 0 & 0 & 0 & 1 & 1 \\
\hline Total & 30 & 29 & 30 & 27 & 26 & 27 & 28 & 197 \\
\hline \multicolumn{9}{|c|}{ Panel D. Summary statistics of quality of carbon emission disclosure. } \\
\hline Variable & $\mathbf{N}$ & Mean & \multicolumn{2}{|c|}{ Median } & St.Dev & \multicolumn{2}{|c|}{ Minimum } & Maximun \\
\hline Overall & 356 & 5.91 & \multicolumn{2}{|c|}{6} & 4.67 & \multicolumn{2}{|c|}{0} & 22 \\
\hline $\begin{array}{l}\text { Central } \\
\text { SOEs }\end{array}$ & 159 & 6.57 & \multicolumn{2}{|c|}{7} & 5.18 & \multicolumn{2}{|c|}{0} & 22 \\
\hline $\begin{array}{l}\text { Local } \\
\text { SOEs }\end{array}$ & 197 & 5.38 & \multicolumn{2}{|c|}{5} & 4.14 & \multicolumn{2}{|c|}{0} & 19 \\
\hline \multicolumn{9}{|l|}{ Year } \\
\hline 2018 & 53 & 7.77 & \multicolumn{2}{|c|}{7} & 5.64 & \multicolumn{2}{|c|}{0} & 22 \\
\hline 2017 & 52 & 7.42 & \multicolumn{2}{|c|}{7} & 5.45 & \multicolumn{2}{|c|}{0} & 22 \\
\hline 2016 & 49 & 6.35 & \multicolumn{2}{|c|}{6} & 4.65 & \multicolumn{2}{|c|}{0} & 16 \\
\hline 2015 & 50 & 6.02 & \multicolumn{2}{|c|}{6} & 4.49 & \multicolumn{2}{|c|}{0} & 19 \\
\hline 2014 & 52 & 4.90 & \multicolumn{2}{|c|}{4.5} & 3.75 & \multicolumn{2}{|c|}{0} & 14 \\
\hline 2013 & 50 & 4.46 & \multicolumn{2}{|c|}{4} & 3.54 & \multicolumn{2}{|c|}{0} & 11 \\
\hline 2012 & 50 & 4.32 & \multicolumn{2}{|c|}{4} & 3.52 & \multicolumn{2}{|c|}{0} & 11 \\
\hline
\end{tabular}

Panel A results are split into Panels B and C for the central and local government-owned companies respectively. Panel B of Table 3 presents the results of Chinese central government-owned electricity companies, showing that central government-owned companies have scored 7 points on average out of a maximum of 54, which is slightly higher than the average scores of 6 points for all SOEs. Our findings indicate that the most frequent score of quality of carbon emission disclosures is 8 out of a total of 54 scores with only 18 firm-year year observations. In contrast, Panel C of Table 3 presents the results of Chinese local government-owned electricity companies, showing that local government-owned companies have scored 5 points on average out of a maximum of 54 points assigned to carbon emission disclosures. Our findings indicate that the most frequent score of quality of carbon emission disclosures is 6 points out of a total of 54, with only 26 firm-year year observations. In a nutshell, the quality of carbon emission disclosures is slightly higher in central government-owned companies than local government-owned companies. 
Panel D of Table 3 presents the descriptive statistics of quality scores of carbon emission disclosure including the average (mean and median), variance statistics (standard deviation), along with the minimum and maximum values of quality of carbon emission disclosures score (0-54). The overall sample has the average values of 5.91 points for mean and 6 points for the median in terms of the quality of the carbon emission disclosures, indicating a very low quality of carbon emission disclosures. Our study shows a lower level of quality of carbon emission disclosures in state-owned electricity companies as compared to the prior study in the Iranian context which reports the average values of 16.19 and 14 of mean and median of the quality of the environmental disclosures respectively [52]. Our study also compares the quality of carbon emission disclosures between central and local SOEs, indicating that central SOEs have a better quality of carbon emission disclosures as compared to local SOEs. Finally, the yearly comparison indicates that the quality of carbon emission disclosures was improving from 2012 to 2018 and recent years of 2018 and 2017 had a better quality score of carbon emission disclosures as compared to other years.

Table 4 illustrates the descriptive statistics of variables. There are in total of 356 firm-year observations. Table 4 presents the average (mean and median) and variance statistics (standard deviation) along with the first and ninety-ninth quartiles of the variables used in this study. The average value of the quality of the carbon emission disclosure index is 0.11 , indicating that the quality of carbon emission disclosures is around $11 \%$ out of $100 \%$ (54) maximum scores. The independent variable, i.e., participation in ETS, has an average value of 0.24 , indicating around $24 \%$ of companies were participating in CN-ETS throughout 2012-2018. The level of internal control has an average value of 6.49 , indicating that Chinese state-owned companies have a moderate level of internal control.

Table 4. Summary of descriptive statistics of variables.

\begin{tabular}{ccccccc}
\hline Variable & $\mathbf{N}$ & Mean & St.Dev & p1 & Median & p99 \\
\hline QCDI & 356 & 0.11 & 0.09 & 0.00 & 0.11 & 0.35 \\
ETS & 356 & 0.24 & 0.43 & 0.00 & 0.00 & 1.00 \\
T & 356 & 0.71 & 0.45 & 0.00 & 1.00 & 1.00 \\
LCE & 356 & 6.49 & 0.17 & 5.70 & 6.50 & 6.84 \\
LEV & 356 & 0.59 & 0.19 & 0.07 & 0.60 & 0.93 \\
ROA & 356 & 0.03 & 0.05 & -0.10 & 0.03 & 0.16 \\
DUAL & 356 & 0.91 & 0.29 & 0.00 & 1.00 & 1.00 \\
SIZE & 356 & 23.36 & 1.46 & 20.57 & 23.38 & 26.44 \\
GROW & 356 & 24.60 & 1.76 & 20.04 & 24.61 & 28.19 \\
BS & 356 & 2.29 & 0.23 & 1.79 & 2.20 & 2.83 \\
BIG4 & 356 & 0.07 & 0.25 & 0.00 & 0.00 & 1.00 \\
\hline
\end{tabular}

Table 5 describes the Pearson correlation for the sample, showing that the quality of carbon emission disclosures (QCDI) has a positive and significant association with participation in CN-ETS as expected. Likewise, there is a positive and significant relationship between the quality of the carbon emission disclosures and the level of internal control (LCE). Regarding the correlation between independent variables, we find the highest correlation value of 0.36 between firm size and board size, which does not exceed from the cut point 0.7 . Thus, there is less chance to have multicollinearity in our model.

The main results of this study conducted by using the DID method are shown in Table 6. We find that there is a positive and significant relationship between companies' participation in CN-ETS and the quality of carbon emission disclosures (model 1), which indicates that Chinese state-owned companies that participate in CN-ETS, provide relatively higher quality carbon emission disclosures. The DID estimation, interaction of $\mathrm{T} *$ ETS significantly influences the quality of carbon emission disclosures, which indicates that CN-ETS implementation improves the quality of carbon emission disclosures of Chinese state-owned electricity companies. Our findings strongly support hypothesis 1 and are generally in line with legitimacy theory and results of prior studies. Our findings suggest that the 
CN-ETS pilot scheme plays an important role in enhancing the quality of carbon emission disclosures for different stakeholders. Our study contributes to contemporary research on CN-ETS in China $[45,48]$.

Table 5. Correlation analysis.

\begin{tabular}{|c|c|c|c|c|c|c|c|c|c|c|c|}
\hline Variables & (1) & (2) & (3) & (4) & (5) & (6) & (7) & (8) & (9) & (10) & (11) \\
\hline (1) QCDI & 1.00 & & & & & & & & & & \\
\hline (2) ETS & 0.27 * & 1.00 & & & & & & & & & \\
\hline (3) $\mathrm{T}$ & 0.20 * & $0.32 *$ & 1.00 & & & & & & & & \\
\hline (4) LCE & 0.15 * & -0.08 & $-0.18^{*}$ & 1.00 & & & & & & & \\
\hline (5) LEV & -0.05 & 0.03 & $-0.12 *$ & -0.05 & 1.00 & & & & & & \\
\hline (6) ROA & 0.03 & -0.06 & 0.00 & $0.18 *$ & $-0.36 *$ & 1.00 & & & & & \\
\hline (7) DUAL & 0.05 & 0.06 & -0.09 & $0.13 *$ & -0.04 & 0.04 & 1.00 & & & & \\
\hline (8) SIZE & 0.47 * & $0.23 *$ & 0.14 * & 0.24 * & $0.26 *$ & 0.06 & 0.21 * & 1.00 & & & \\
\hline (9) GROW & $0.18^{*}$ & 0.09 & -0.03 & $0.16^{*}$ & 0.07 & 0.00 & 0.03 & 0.27 * & 1.00 & & \\
\hline (10) BS & 0.29 * & 0.17 * & -0.09 & 0.14 * & $0.26^{*}$ & 0.00 & 0.17 * & $0.36 *$ & 0.09 & 1.00 & \\
\hline (11) BIG4 & 0.26 * & $0.13 *$ & 0.02 & 0.10 & 0.06 & 0.02 & 0.09 & $0.35 *$ & $0.22 *$ & 0.35 * & 1.00 \\
\hline
\end{tabular}

Table 6. Main results of the impact of CN-ETS and internal control on the quality of carbon emission disclosures.

\begin{tabular}{cccc}
\hline Variable & $\mathbf{( 1 )}$ & $\mathbf{( 2 )}$ & $\mathbf{( 3 )}$ \\
\hline & Overall & C_SOEs & L_SOEs \\
\hline ETS & $0.035^{*}$ & $0.032^{*}$ & 0.030 \\
& $(0.019)$ & $(0.019)$ & $(0.027)$ \\
T & 0.024 & $0.046^{* *}$ & 0.005 \\
T * ETS & $(0.028)$ & $(0.020)$ & $(0.014)$ \\
& $0.057^{* * *}$ & $0.085^{* * *}$ & 0.033 \\
LCE & $(0.023)$ & $(0.029)$ & $(0.027)$ \\
& $0.022^{* * *}$ & $0.034^{* * *}$ & 0.008 \\
LEV & $(0.003)$ & $(0.004)$ & $(0.005)$ \\
& $-0.105^{* * *}$ & $-0.131^{* *}$ & $-0.087 * *$ \\
ROA & $(0.028)$ & $(0.052)$ & $(0.034)$ \\
& $-0.157^{*}$ & 0.094 & $-0.204 * *$ \\
DUAL & $(0.093)$ & $(0.284)$ & $(0.087)$ \\
& $-0.027^{*}$ & $-0.080^{* *}$ & -0.000 \\
SIZE & $(0.015)$ & $(0.040)$ & $(0.016)$ \\
& $0.016^{*}$ & 0.015 & $0.026^{* *}$ \\
GROW & $(0.009)$ & $(0.015)$ & $(0.012)$ \\
& 0.034 & $0.056^{* *}$ & 0.039 \\
BS & $(0.035)$ & $(0.028)$ & $(0.029)$ \\
& $0.081^{* * *}$ & $0.067^{* *}$ & $0.066^{* * *}$ \\
R-squared & $(0.017)$ & $(0.029)$ & $(0.023)$ \\
Year & 0.012 & $-0.048^{* *}$ & $0.083 * * *$ \\
Constant & $-0.537^{* * *}$ & $-0.704^{* * *}$ & $-0.228^{*}$ \\
& $(0.077)$ & $(0.106)$ & $(0.116)$ \\
& 356 & 159 & 197 \\
& 0.361 & 0.498 & 0.330 \\
& Yes & Yes & Yes \\
\hline
\end{tabular}

Notes: Robust standard errors in parentheses. ${ }^{* * *} p<0.01,{ }^{* *} p<0.05,{ }^{*} p<0.1$. Overall: the whole sample of the study; C_SOEs: the central government-owned companies sub-sample; and L_SOEs: the local government-owned companies sub-sample. Variable definitions are given in Table 1. 
Table 6 also reveals that the level of internal control (LCE) has a positive and significant relationship with the quality of the carbon emission disclosures, indicating the higher level of internal control is associated with the quality of carbon emission disclosures, which supports hypothesis 2 . Thus, our findings suggest that effective internal control enhances the disclosure quality of carbon emissions of Chinese state-owned electricity companies and this is in line with prior studies [18,20].

Models 2 and 3 of Table 6 present the results of the sub-samples of central and local government-owned electricity companies, respectively, showing that only in the central government-owned companies subsample, the results are significant. The findings indicate that central government-owned electricity companies perform better in meeting the carbon emission disclosures demand of their stakeholders as indicated by their higher value of median score of 7 of the quality of carbon emission disclosures as compared to 5 median value of the quality of carbon emission disclosures of local government-owned electricity companies.

Table 7 provides the sensitivity tests of the study using five dimensions of carbon emission disclosures as dependent variables. We find similar results as the main study described before. However, the results of quality of climate risks and opportunities disclosures are more pronounced as compared to the other dimensions due to the higher values of their coefficients of the interaction of time period and participation of CN-ETS (T *ETS) and the level of internal control.

Table 7. Sensitivity tests.

\begin{tabular}{|c|c|c|c|}
\hline \multicolumn{4}{|c|}{ Panel A: Quality of Climate Risks and Opportunities Disclosures } \\
\hline \multirow[t]{2}{*}{ Variable } & (1) & (2) & (3) \\
\hline & Overall & C_SOEs & L_SOEs \\
\hline \multirow[t]{2}{*}{ ETS } & $0.284^{* * *}$ & $0.394^{* * *}$ & 0.041 \\
\hline & $(0.106)$ & $(0.131)$ & $(0.211)$ \\
\hline \multirow[t]{2}{*}{$\mathrm{T}$} & 0.299 & $0.672^{* * *}$ & 0.004 \\
\hline & $(0.288)$ & $(0.166)$ & $(0.179)$ \\
\hline \multirow[t]{2}{*}{$\mathrm{T} * \mathrm{ETS}$} & $0.479^{* * *}$ & $0.333^{* *}$ & 0.254 \\
\hline & $(0.174)$ & $(0.154)$ & $(0.206)$ \\
\hline \multirow[t]{2}{*}{ LCE } & $0.158^{* *}$ & $0.204^{* *}$ & 0.063 \\
\hline & $(0.072)$ & $(0.092)$ & $(0.114)$ \\
\hline Control & Included & Included & Included \\
\hline Observations & 356 & 159 & 197 \\
\hline R-squared & 0.202 & 0.333 & 0.197 \\
\hline Year & Yes & Yes & Yes \\
\hline \multicolumn{4}{|c|}{ Panel B: Quality of GHG emission accounting disclosures. } \\
\hline \multirow[t]{2}{*}{ ETS } & $0.218^{* *}$ & $0.195^{* *}$ & 0.017 \\
\hline & $(0.106)$ & $(0.082)$ & $(0.023)$ \\
\hline \multirow[t]{2}{*}{$\mathrm{T}$} & 0.028 & 0.026 & 0.019 \\
\hline & $(0.022)$ & $(0.050)$ & $(0.019)$ \\
\hline \multirow[t]{2}{*}{$\mathrm{T}^{*}$ ETS } & $0.138^{* * *}$ & $0.167^{* * *}$ & 0.055 \\
\hline & $(0.042)$ & $(0.031)$ & $(0.043)$ \\
\hline \multirow[t]{2}{*}{ LCE } & $0.108^{* *}$ & $0.154^{* *}$ & 0.013 \\
\hline & $(0.052)$ & $(0.072)$ & $(0.064)$ \\
\hline Control & Included & Included & Included \\
\hline Observations & 356 & 159 & 197 \\
\hline R-squared & 0.140 & 0.220 & 0.218 \\
\hline Year & Yes & Yes & Yes \\
\hline
\end{tabular}


Table 7. Cont.

\begin{tabular}{|c|c|c|c|}
\hline \multicolumn{4}{|c|}{ Panel C: Quality of energy consumption accounting disclosures. } \\
\hline \multirow[t]{2}{*}{ ETS } & $0.333 * *$ & $0.384^{* *}$ & 0.204 \\
\hline & $(0.169)$ & $(0.181)$ & $(0.196)$ \\
\hline \multirow[t]{2}{*}{$\mathrm{T}$} & 0.034 & 0.114 & 0.046 \\
\hline & $(0.142)$ & $(0.220)$ & $(0.193)$ \\
\hline \multirow[t]{2}{*}{$\mathrm{T} * \mathrm{ETS}$} & $0.152^{* * *}$ & $0.212^{* * *}$ & 0.058 \\
\hline & $(0.041)$ & $(0.050)$ & $(0.066)$ \\
\hline \multirow[t]{2}{*}{ LCE } & $0.098^{* * *}$ & $0.187^{* * *}$ & $0.055 * *$ \\
\hline & $(0.024)$ & $(0.034)$ & $(0.026)$ \\
\hline Control & Included & Included & Included \\
\hline Observations & 356 & 159 & 197 \\
\hline R-squared & 0.090 & 0.271 & 0.114 \\
\hline Year & Yes & Yes & Yes \\
\hline \multicolumn{4}{|c|}{ Panel D: Quality of GHG reduction and cost disclosures. } \\
\hline \multirow[t]{2}{*}{ ETS } & $0.198^{*}$ & 0.057 & 0.239 \\
\hline & $(0.114)$ & $(0.100)$ & $(0.168)$ \\
\hline \multirow[t]{2}{*}{$\mathrm{T}$} & 0.015 & 0.084 & 0.031 \\
\hline & $(0.074)$ & $(0.123)$ & $(0.089)$ \\
\hline \multirow[t]{2}{*}{$\mathrm{T}^{*}$ ETS } & $0.292 * *$ & $0.393^{* *}$ & 0.227 \\
\hline & $(0.129)$ & $(0.180)$ & $(0.159)$ \\
\hline \multirow[t]{2}{*}{ LCE } & $0.097 *$ & 0.127 * & 0.057 \\
\hline & $(0.058)$ & $(0.075)$ & $(0.057)$ \\
\hline Control & Included & Included & Included \\
\hline Observations & 356 & 159 & 197 \\
\hline R-squared & 0.306 & 0.437 & 0.430 \\
\hline Year & Yes & Yes & Yes \\
\hline \multicolumn{4}{|c|}{ Panel E: Quality of carbon emission accountability disclosures. } \\
\hline \multirow[t]{2}{*}{ ETS } & $0.041^{* * *}$ & $0.046^{* *}$ & 0.026 \\
\hline & $(0.015)$ & $(0.022)$ & $(0.022)$ \\
\hline \multirow[t]{2}{*}{$\mathrm{T}$} & 0.047 & 0.104 & 0.036 \\
\hline & $(0.140)$ & $(0.074)$ & $(0.151)$ \\
\hline \multirow[t]{2}{*}{$\mathrm{T} * \mathrm{ETS}$} & $0.279 * * *$ & $0.307^{* * *}$ & 0.131 \\
\hline & $(0.102)$ & $(0.062)$ & $(0.161)$ \\
\hline \multirow[t]{2}{*}{ LCE } & $0.071^{*}$ & $0.096^{*}$ & 0.059 \\
\hline & $(0.041)$ & $(0.053)$ & $(0.062)$ \\
\hline Control & Included & Included & Included \\
\hline Observations & 356 & 159 & 197 \\
\hline R-squared & 0.281 & 0.338 & 0.310 \\
\hline Year & Yes & Yes & Yes \\
\hline
\end{tabular}

Notes: Robust standard errors in parentheses. ${ }^{* * *} \mathrm{p}<0.01{ }^{* *} \mathrm{p}<0.05,{ }^{*} \mathrm{p}<0.1$. Overall: the whole sample of the study; C_SOEs: the central government-owned companies sub-sample; and L_SOEs: the local government-owned companies sub-sample. Variable definitions are given in Table 1.

\section{Conclusions}

The quality of carbon emission disclosures is the main concern of stakeholders of companies. Using hand-collected data on the quality of carbon emission disclosures of Chinese state-owned companies for 2012-2018, our study documents that companies participate in CN-ETs pilot schemes are associated with higher quality carbon emission disclosures. Our study also concludes that companies with a higher level of internal control provide more transparent and better quality carbon emission disclosures. The findings are more pronounced in the case of central government-owned companies. Our study contributes to the contemporary carbon emission disclosure literature by providing empirical evidence on the importance of a company participating in CN-ETs and internal control in enhancing the quality of carbon emission disclosures. Our findings have implications for managers and regulators of electricity companies in China. To enhance the quality of carbon emission disclosures, the regulators 
should assist the companies with appropriate guidelines regarding the preparation of sustainability reports and carbon emission disclosures. For managers, it is clear that Chinese state-owned electricity companies can legitimize their actions by providing a higher quality of carbon emission disclosures. Of course, our findings should be interpreted with some cautions as our study is limited to only the electricity sector. The upcoming studies should examine these issues in different sectors.

Author Contributions: Conceptualization, D.T., B., and S.G.; methodology, B. and B.K.; software, B.; validation, B.K., S.G., and D.T.; formal analysis, B.K., B., and D.T. writing-original draft preparation, S.G.; writing-review and editing, B. and D.T.; supervision, S.G.; project administration, B.; funding acquisition, D.T. All authors have read and agreed to the published version of the manuscript.

Funding: This research is a phase result of the project entitled A Study On How Carbon Asset Management Risk May Impact Management Accounting funded by the Institute of Management Accountants (IMA), Management Consulting Ltd., Beijing, China, and the project of Research on Carbon Emissions Trading Accounting and Financial Operation Risk, which is funded by Hubei University of Economics.

Acknowledgments: We acknowledge the support of Master students (e.g., Liu Jing, Guo Mengyun, Zhang Zhen, Feng Xin, Yuan Ye, Guo Mengxuan, Deng Siqi, and An Chengxia) of Accounting School from the Hubei University of Economics with the help of collecting data.

Conflicts of Interest: The authors declare no conflict of interest.

\section{References}

1. Mayer, B.; Rajavuori, M.; Fang, M.M. The contribution of state-owned enterprises to climate change mitigation in China. Clim. Law 2017, 7, 97-124. [CrossRef]

2. Wang, F.; Sun, J.; Liu, Y.S. Institutional pressure, ultimate ownership, and corporate carbon reduction engagement: Evidence from China. J. Bus. Res. 2019, 104, 14-26. [CrossRef]

3. Nelson, M.; Bell, M. How Climate Change Disclosures Reveal Business Risks and Opportunities. Available online: https://www.ey.com/en_gl/assurance/climate-change-disclosures-revealing-risks-opportunities (accessed on 30 December 2019).

4. Li, H.Y.; Fu, S.Y.; Chen, Z.; Shi, J.; Yang, Z.Y.; Li, Z.H. The motivations of Chinese firms in response to the carbon disclosure project. Environ. Sci. Pollut. Res. 2019, 26, 27792-27807. [CrossRef] [PubMed]

5. Wang, Y.; Su, X.; Qi, L.; Shang, P.; Xu, Y.J.E.S.; Research, P. Feasibility of peaking carbon emissions of the power sector in China's eight regions: Decomposition, decoupling, and prediction analysis. Environ. Sci. Pollut. Res. 2019, 26, 29212-29233. [CrossRef] [PubMed]

6. Wu, J.; Tang, G.; Wang, R.; Yanwei, S. Multi-objective optimization for China's power carbon emission reduction by 2035. J. Therm. Sci. 2019, 28, 184-194. [CrossRef]

7. Momin, M.A.; Northcott, D.; Hossain, M. Greenhouse gas disclosures by Chinese power companies: Trends, content and strategies. J. Account. Organ. Chang. 2017, 13, 331-358. [CrossRef]

8. Liu, X.; Du, H.B.; Brown, M.A.; Zuo, J.; Zhang, N.; Rong, Q.; Mao, G.Z. Low-carbon technology diffusion in the decarbonization of the power sector: Policy implications. Energy Policy 2018, 116, 344-356. [CrossRef]

9. Zeng, M.; Yang, Y.Q.; Wang, L.H.; Sun, J.H. The power industry reform in China 2015: Policies, evaluations and solutions. Renew. Sustain. Energy Rev. 2016, 57, 94-110. [CrossRef]

10. Stoerk, T.; Dudek, D.J.; Yang, J. China's national carbon emissions trading scheme: Lessons from the pilot emission trading schemes, academic literature, and known policy details. Clim. Policy 2019, 19, 472-486. [CrossRef]

11. UNDP. Good Practice: China ETS Pilots, Carbon Markets. Available online: https: //www.transparency-partnership.net/system/files/document/Good\%20Practice-China-China\%20ETS\% 20Pilots\%2C\%20Carbon\%20Markets.pdf (accessed on 31 January 2020).

12. Li, W.; Zhang, Y.W.; Lu, C. The impact on electric power industry under the implementation of national carbon trading market in China: A dynamic CGE analysis. J. Clean. Prod. 2018, 200, 511-523. [CrossRef]

13. Qian, H.Q.; Zhou, Y.; Wu, L.B. Evaluating various choices of sector coverage in China's national emissions trading system (ETS). Clim. Policy 2018, 18, 7-26. [CrossRef]

14. Menezes, F.M.; Zheng, X.M. Regulatory incentives for a low-carbon electricity sector in China. J. Clean. Prod. 2018, 195, 919-931. [CrossRef] 
15. Li, X.; Zheng, C.M.; Liu, G.; Sial, M.S. The effectiveness of internal control and corporate social responsibility: Evidence from Chinese capital market. Sustainability 2018, 10, 4006. [CrossRef]

16. Liu, J.Y. An internal control system that includes corporate social responsibility for social sustainability in the new era. Sustainability 2018, 10, 3382. [CrossRef]

17. Wang, Y.C.; Tang, M.P.; Yu, X. Can the high quality of internal control promote the fulfillment of corporate social responsibility in energy enterprises? In Proceedings of the 2015 Asia-Pacific Energy Equipment Engineering Research Conference, Zhuhai, China, 13-14 June 2015; Volume 9, pp. 526-530.

18. Ren, X.; Li, Q. The relationship between the quality of carbon information disclosure and the level of internal control: A case study of Chinese enterprises in CDP project. MOD Account 2018, 8, 12-16.

19. Chen, L. Research on managerial power, internal control and corporate environmental disclosure. Ecol. Econ. 2016, 32, 90-93.

20. Qiao, Y. Empirical study on the relationship between the effectiveness of internal control and the quality of environmental information disclosure. Stat. Decis. Mak. 2015, 23, 166-169.

21. Choi, B.B.; Lee, D.; Psaros, J. An analysis of Australian company carbon emission disclosures. Pac. Account. Rev. 2013, 25, 58-79. [CrossRef]

22. Lee, K.-H. Does size matter? Evaluating corporate environmental disclosure in the Australian mining and metal industry: A combined approach of quantity and quality measurement. Bus. Strategy Environ. 2017, 26, 209-223. [CrossRef]

23. Li, J.; Zhang, Y. Policy implications for carbon trading market establishment in China in the 12th five-year period. Adv. Clim. Chang. Res. 2012, 3, 163-173.

24. Liu, Q.; Zheng, X.-Q.; Zhao, X.-C.; Chen, Y.; Lugovoy, O. Carbon emission scenarios of China's power sector: Impact of controlling measures and carbon pricing mechanism. Adv. Clim. Chang. Res. 2018, 9, 27-33. [CrossRef]

25. Yan, H.; Huang, Y. Construction of accounting system for carbon emission rights. Friends Account 2016, 5, 8-11. (In Chinese)

26. Zhang, L.; Zeng, Y.; Li, D. China's emissions trading scheme: First evidence on pilot stage. Pol. J. Environ. Stud. 2019, 28, 543-551. [CrossRef]

27. Zhang, L.; Cao, C.; Tang, F.; He, J.; Li, D. Does China's emissions trading system foster corporate green innovation? Evidence from regulating listed companies. Technol. Anal. Strateg. Manag. 2019, 31, 199-212. [CrossRef]

28. Jotzo, F.; Löschel, A. Emissions Trading in China: Emerging Experiences and International Lessons; Elsevier: Amsterdam, The Netherlands, 2014.

29. Liu, L.; Chen, C.; Zhao, Y.; Zhao, E. China's carbon-emissions trading: Overview, challenges and future. Renew. Sustain. Energy Rev. 2015, 49, 254-266. [CrossRef]

30. Zhang, D.; Karplus, V.J.; Cassisa, C.; Zhang, X. Emissions trading in China: Progress and prospects. Energy Policy 2014, 75, 9-16. [CrossRef]

31. Zhao, X.-G.; Wu, L.; Li, A. Research on the efficiency of carbon trading market in China. Renew. Sustain. Energy Rev. 2017, 79, 1-8. [CrossRef]

32. Dong, J.; Ma, Y.; Sun, H. From pilot to the national emissions trading scheme in China: International practice and domestic experiences. Sustainability 2016, 8, 522. [CrossRef]

33. Shen, H.; Dai, Y.; Zhang, J. Carbon emission trading mechanism and carbon transparency of enterprises. Financ. Account. Mon. 2018, 1, 151-161.

34. Tang, Q.; Luo, L. Transparency of corporate carbon disclosure: International evidence. SSRN 2011. [CrossRef]

35. Bebbington, J.; Larrinaga-Gonzalez, C. Carbon trading: Accounting and reporting issues. Eur. Account. Rev. 2008, 17, 697-717. [CrossRef]

36. Kashyap, V.N. Determinants of Carbon Financial Accounting and Carbon Disclosure Practices: An Exploratory Study on Firms Affected under Emission Trading Schemes. Ph.D. Thesis, Massey University, Albany, New Zealand, 2016.

37. Ashforth, B.E.; Gibbs, B.W. The double-edge of organizational legitimation. Organ. Sci. 1990, 1, 177-194. [CrossRef]

38. Freeman, R.E. The Development of Stakeholder Theory: An Idiosyncratic Approach; Great Minds Management: Oxford, UK, 2005; pp. 417-435. 
39. Zhou, Z.; Zhou, H.; Peng, D.; Chen, X.-H.; Li, S.-H. Carbon disclosure, financial transparency, and agency cost: Evidence from Chinese manufacturing listed companies. Emerg. Mark. Financ. Trade 2018, 54, 2669-2686. [CrossRef]

40. Kalu, J.; Aliagha, G.; Buang, A. A review of economic factors influencing voluntary carbon disclosure in the property sector of developing economies. In Proceedings of the 3rd International Conference on Geological, Geographical, Aerospace and Earth Science, Jakarta, Indonesia, 26-27 September 2015.

41. Leung, Z.B.G.; Philomena, L. An empirical analysis of the determinants of greenhouse gas voluntary disclosure in Australia. Account. Financ. Res. 2013, 2. [CrossRef]

42. Kelley, T.P. The COSO report: Challenge and counterchallenge. J. Account. 1993, 175, 10.

43. Johnstone, K.; Li, C.; Rupley, K.H. Changes in corporate governance associated with the revelation of internal control material weaknesses and their subsequent remediation. Contemp. Account. Res. 2011, 28, 331-383. [CrossRef]

44. Li, Z.; Zhang, T. Internal control, nature of property right and social responsibility information disclosure: Evidence from Chinese listed companies. Account. Res. 2017, 10, 86-92. (In Chinese)

45. Shen, H.-T.; Huang, N.; Liu, L. A study of the micro-effect and mechanism of the carbon emission trading scheme. J. Xiamen Univ. Philos. Soc. Sci. Ed. 2017, 1, 13-22. (In Chinese)

46. Feng, C.; Shi, B.; Kang, R. Does environmental policy reduce enterprise innovation?-Evidence from China. Sustainability 2017, 9, 872. [CrossRef]

47. Zang, J.; Wan, L.; Li, Z.; Wang, C.; Wang, S. Does emission trading scheme have spillover effect on industrial structure upgrading? Evidence from the EU based on a PSM-DID approach. Environ. Sci. Pollut. Res. 2020. [CrossRef]

48. Zhang, W.; Li, J.; Li, G.; Guo, S. Emission reduction effect and carbon market efficiency of carbon emissions trading policy in China. Energy 2020, 196, 117117. [CrossRef]

49. Cheng, Z.; Wang, F.; Keung, C.; Bai, Y. Will corporate political connection influence the environmental information disclosure level? Based on the panel data of A-shares from listed companies in shanghai stock market. J. Bus. Ethics 2017, 143, 209-221. [CrossRef]

50. Luo, X.R.; Wang, D. Are politically endorsed firms more socially responsible? Selective engagement in corporate social responsibility. J. Bus. Ethics 2019. [CrossRef]

51. Lu, J.; Li, B.; Li, H.; Zhang, Y. Sustainability of enterprise export expansion from the perspective of environmental information disclosure. J. Clean. Prod. 2019. [CrossRef]

52. Alipour, M.; Ghanbari, M.; Jamshidinavid, B.; Taherabadi, A. Does board independence moderate the relationship between environmental disclosure quality and performance? Evidence from static and dynamic panel data. Corp. Gov. Int. J. Bus. Soc. 2019, 19, 580-610. [CrossRef] 